University of Nebraska - Lincoln

DigitalCommons@University of Nebraska - Lincoln

Roman L. Hruska U.S. Meat Animal Research

U.S. Department of Agriculture: Agricultural Center

Research Service, Lincoln, Nebraska

2016

\title{
Mitochondrial abundance and efficiency contribute to lean color of dark cutting beef
}

\author{
Russell O. McKeith \\ Texas A\&M University \\ D. Andy King \\ USDA-ARS, andy.king@usda.gov \\ Adria L. Grayson \\ Texas A\&M University \\ Steven D. Shackelford \\ USDA-ARS
}

Kerri B. Gehring

Texas A\&M University

See next page for additional authors

Follow this and additional works at: https://digitalcommons.unl.edu/hruskareports

McKeith, Russell O.; King, D. Andy; Grayson, Adria L.; Shackelford, Steven D.; Gehring, Kerri B.; Savell, Jeffrey W.; and Wheeler, Tommy L., "Mitochondrial abundance and efficiency contribute to lean color of dark cutting beef" (2016). Roman L. Hruska U.S. Meat Animal Research Center. 398.

https://digitalcommons.unl.edu/hruskareports/398

This Article is brought to you for free and open access by the U.S. Department of Agriculture: Agricultural Research Service, Lincoln, Nebraska at DigitalCommons@University of Nebraska - Lincoln. It has been accepted for inclusion in Roman L. Hruska U.S. Meat Animal Research Center by an authorized administrator of DigitalCommons@University of Nebraska - Lincoln. 


\section{Authors}

Russell O. McKeith, D. Andy King, Adria L. Grayson, Steven D. Shackelford, Kerri B. Gehring, Jeffrey W.

Savell, and Tommy L. Wheeler 


\title{
Mitochondrial abundance and efficiency contribute to lean color of dark cutting beef
}

\author{
Russell O. McKeith ${ }^{\mathrm{a}, 1}$, D. Andy King ${ }^{\mathrm{b}, *}$, Adria L. Grayson ${ }^{\mathrm{a}, 2}$, Steven D. Shackelford ${ }^{\mathrm{b}}$, Kerri B. Gehring ${ }^{\mathrm{a}}$, \\ Jeffrey W. Savell ${ }^{\mathrm{a}}$, Tommy L. Wheeler ${ }^{\mathrm{b}}$ \\ a Department of Animal Science, Texas AEM AgriLife Research, Texas AE'M University, College Station 77843-2471, United States \\ b USDA-ARS, Roman L. Hruska US Meat Animal Research Center, Clay Center, NE 68933, United States
}

\section{A R T I C L E I N F O}

Article history:

Received 18 June 2015

Received in revised form 23 November 2015

Accepted 18 January 2016

Available online 30 January 2016

\section{Keywords:}

Dark cutting beef

Color

Color stability

Electron transport

Mitochondria

\begin{abstract}
A B S T R A C T
Beef carcasses exhibiting four levels of dark cutting severity (DCS): Severe, Moderate, Mild, and Shady were compared to Control carcasses to investigate biochemical traits contributing to the dark cutting condition. Color attributes of Longissimus lumborum (LL) were measured after grading and during simulated retail display. Mitochondrial abundance and efficiency, bloomed oxymyoglobin, reducing ability, glycolytic potential, myoglobin concentration, and protein solubility and oxidation were determined. Glycolytic potential and lactate concentrations decreased $(P<0.05)$ as DCS increased. Residual glycogen was greater $(P<0.05)$ in steaks from Control carcasses compared to DCS classes. Generally, as DCS increased, LL steaks were darker and less red in color $(P<0.05)$. Increased $(P<0.05)$ oxygen consumption and reducing ability coincided with greater myoglobin concentration and greater abundance of less efficient mitochondria as DCS increased $(P<0.05)$. These data suggest the dark cutting condition is associated with greater oxidative metabolism coupled with less efficient mitochondria resulting in depletion of glycogen during stress.
\end{abstract}

Published by Elsevier Ltd.

\section{Introduction}

The dark lean color, and firm and dry texture of dark cutting beef does not meet expectations for beef product appearance and thus, is discriminated against by consumers. Moreover, dark cutting beef has been associated with increased incidence of off-flavor and greater variability in tenderness compared to normal beef (Calkins \& Hodgen, 2007; Wulf, Emnett, Leheska, \& Moeller, 2002). Consequently, dark cutting beef is severely discounted by beef packers at a great cost to livestock producers. According to the 2011 National Beef Quality Audit, 3.5\% of carcasses presented for grading were affected by the dark cutting condition (Moore et al., 2012).

Dark cutting beef is attributed to depletion of muscle glycogen resulting in a less-than-normal $\mathrm{pH}$ decline after slaughter, and consequently, greater-than-normal muscle $\mathrm{pH}$. The depletion of muscle glycogen is thought to be due to long-term stress prior to slaughter. However, the dark cutting condition occurs in a relatively small number of carcasses, and within production lots that are housed and managed together during the weeks leading up to harvest, only a small minority of animals will produce carcasses that display the dark cutting

\footnotetext{
* Corresponding author.

E-mail address: andy.king@ars.gov (D.A. King).

Present address: College of Sequoias Tulare College Center, Division of Agriculture, Tulare, CA 93274, United States.

2 Present address: Sadler's Smokehouse, Henderson, TX 75652, United States.
}

condition. Thus, a greater understanding of the factors predisposing animals to produce carcasses with the dark cutting condition is needed.

Dark cutting beef has been associated with a higher mitochondrial respiration rate, which helps maintain low oxymyoglobin concentrations. Ashmore et al. (1973) and Lawrie (1958) both reported that reduced postmortem muscle $\mathrm{pH}$ impairs the overall level of oxygen consumption in normal muscle compared to high $\mathrm{pH}$ muscle. These findings would suggest that mitochondrial function may play a role in dark cutting beef. However, it is not clear whether this is a causative relationship or a function of the high $\mathrm{pH}$ resulting in conditions more favorable to maintain mitochondrial function postmortem. Therefore, the objectives of the present study were to investigate mitochondrial and glycolytic metabolic traits contributing to lean color and lean color stability in dark cutting and normal beef.

\section{Materials and methods}

Animal care and use committee approval was not obtained for this study because samples were obtained postmortem from a USDA inspected plant.

\subsection{Sample handling and preparation}

Beef carcasses ( $n=320$ ) were selected from a commercial processing facility that processes young, grain-fed steers and heifers. Carcasses were evaluated as they were presented for grading at approximately 
$36 \mathrm{~h}$ postmortem. Selection was conducted on 5 selection days over a 2month-long period. All carcasses selected for inclusion in the present study exhibited A maturity scores (9-30 months of age). Carcasses exhibiting the dark cutting condition $(n=160)$ were subjectively identified by trained evaluators. When a dark cutter was identified, a cohort exhibiting normal lean color and firmness with a similar marbling score was selected from the same production lot (feedlot pen), so that to the greatest extent possible, factors contributing to the incidence of dark cutting such as breed type, animal age, diet, growth promotants, and exposure to stressful stimuli were balanced across the affected and Control groups. Within each selection day, carcasses were assigned to severity groups based on observed muscle pH: Severe, Moderate, Mild, and Shady. Normal cohorts selected to match each dark cutter were included in a separate Control group. Muscle $\mathrm{pH}$ was collected with a Reed SD-230 handheld pH meter (Reed Instruments, Wilmington, NC) on the anterior surface of the Longissimus lumborum exposed by ribbing between the 12th and 13th rib on the right side of each carcass. Carcass grade characteristics were collected using an image analysis-based (VBG2000LED) grading system (Shackelford, Wheeler, \& Koohmaraie, 2003).

After grading, carcasses were placed on a stationary rail and lean color was assessed with a Hunter Miniscan XE Plus Colorimeter (Hunter-Lab, Reston, VA) with a 25-mm port. The colorimeter was set to collect spectral data with Illuminant $A$ and a $10^{\circ}$ observer. The CIE $\mathrm{L}^{*}$ (lightness), $\mathrm{a}^{*}$ (redness), and $\mathrm{b}^{*}$ (yellowness) color-space values were reported as the average of duplicate readings taken on the anterior exposed surface of the longissimus thoracis at the 12th-13th rib interface of the left side of each carcass. After fabrication, the beef, loin, strip loin (similar to IMPS \#180; (NAMP, 2003; USDA, 1996), which includes the longissimus lumborum, were obtained from the left side of each carcass. Subprimals were transported via refrigerated truck $\left(0{ }^{\circ} \mathrm{C}\right)$ to the U.S. Meat Animal Research Center abattoir and aged until $13 \mathrm{~d}$ postmortem.

On day 13 postmortem, the most anterior $13 \mathrm{~cm}$ of each subprimal was removed and utilized in a concurrent research project. The remaining portion of the subprimal was cut into steaks of which the longissimus lumborum was used for subsequent measurements. The first steak $(2.54 \mathrm{~cm})$ was placed immediately in simulated retail display. The second steak $(2.54 \mathrm{~cm})$ was utilized for oxygen consumption and metmyoglobin reducing ability determinations which were completed within $4 \mathrm{~h}$ of the steaks being cut on day 13 postmortem. A third steak $(1.27 \mathrm{~cm})$ was trimmed free of external fat, and visible connective tissue, diced and frozen in liquid nitrogen, and vacuum packaged for storage at $-80^{\circ} \mathrm{C}$ for glycolytic potential, myoglobin concentration, sarcoplasmic protein solubility, sarcoplasmic carbonyl formation determination. The fourth steak $(1.27 \mathrm{~cm})$ was utilized for mitochondrial isolation and determination of mitochondrial efficiency, which was done immediately (13 d postmortem) on fresh, unfrozen tissue.

\subsection{Simulated retail display}

Steaks cut on day 13 postmortem, were placed on polystyrene trays with soaker pads and overwrapped with oxygen-permeable polyvinylchloride (PVC) film [stretchable meat film 55003815; Prime Source, St. Louis, MO; oxygen transmission rate $=1.4 \mathrm{~mL} /\left(\mathrm{cm}^{2} \cdot 24 \mathrm{~h}\right)$ at $23{ }^{\circ} \mathrm{C}$. Steaks then were placed under continuous fluorescent lighting (color temperature $=3500 \mathrm{~K}$; color rendering index $=86$; $32 \mathrm{~W}$; T8 Ecolux bulb, model number F32T8/SPX35, GE, GE Lighting, Cleveland $\mathrm{OH})$ for $11 \mathrm{~d}$. Light intensity at the meat surface was approximately 2000 lx. Retail display was conducted in a refrigerated room $\left(1{ }^{\circ} \mathrm{C}\right)$, and no temperature fluctuations associated with defrost cycles were encountered.

Steaks were allowed to bloom at least $2 \mathrm{~h}$ after being packaged before color measurements were collected. Instrumental color readings were taken on each steak on d $0,1,4,7$, and 11 of display using a Hunter Miniscan XE Plus Colorimeter (Hunter-Lab, Reston, VA) with settings reported earlier. The CIE L* (lightness), a* (redness), and b* (yellowness) color-space values were reported as the average of duplicate readings taken on each steak. Greater $L^{*}, a^{*}$, and $b^{*}$ values signify increased lightness, redness, and yellowness, respectively. Color intensity (also referred to as chroma or saturation index) was calculated using the following formula: $\left[\left(a^{* 2}+b^{* 2}\right)^{0.5}\right]$. Hue angle (redness) was calculated using the formula: [(arctangent $\left.\left(b^{*} / a^{*}\right) \times 180 / 3.142\right]$. Overall color change during retail display (referred to as $\Delta \mathrm{E}$ ) was calculated using the following formula: $\left[\left(\Delta \mathrm{L}^{* 2}+\Delta \mathrm{a}^{* 2}+\Delta \mathrm{b}^{* 2}\right)^{0.5}\right]$, where $\Delta \mathrm{L}^{*}, \Delta \mathrm{a}^{*}$, and $\Delta \mathrm{b}^{*}$ was the difference between $d 0$ and $d 1,4,7$, and 11 values for $L^{*}, a^{*}$, and $b^{*}$, respectively.

\section{3. $\mathrm{pH}$ and total myoglobin concentration}

Steaks designated for determination of total myoglobin concentration were trimmed free of external fat and epimyseal connective tissue, diced, and pulverized in liquid nitrogen to produce a homogenous powder. Myoglobin concentration was determined using a modification of the method reported by Hunt and Hedrick (1977). Duplicate samples $(2.5 \pm 0.05 \mathrm{~g})$ were homogenized in $25 \mathrm{~mL}$ of $800 \mathrm{mM}$ sodium acetate $(\mathrm{pH}=4.5)$. The homogenates were then placed in a shaker at $4{ }^{\circ} \mathrm{C}$ for $1 \mathrm{~h}$ to allow for pigment extraction before centrifugation $(38,000 \times \mathrm{g})$ for $35 \mathrm{~min}$ at $4{ }^{\circ} \mathrm{C}$. The supernatant was then poured into a $50 \mathrm{~mL}$ conical tube. To ensure complete pigment removal, the pellet was washed two times in $10 \mathrm{~mL}$ of cold sodium acetate utilizing vortexing and a glass rod to resuspend the pellet before shaking $\left(4^{\circ} \mathrm{C}\right)$ for $30 \mathrm{~min}$ and then centrifuged as described earlier. Supernatant from both washes were combined with the supernatant from the initial extraction. Supernatant was syringed filtered (Nalgene $0.45 \mu \mathrm{m}$, surfactant-free cellulose acetate membrane; Thermo Fisher Scientific, Rochester, NY) into $1.5 \mathrm{~mL}$ microcentrifuge tube. A $200 \mu \mathrm{L}$ aliquot of the sample was transferred in triplicate to a 96 well plate and blanked against sodium acetate solution. Absorbance spectra at $525 \mathrm{~nm}$ and $700 \mathrm{~nm}$ were collected using a Spectramax plus 96-well plate reader (Molecular Devices, Sunnydale CA). Extracted myoglobin pigment concentration (mg/g meat) was calculated taking the difference between the absorbance at $525 \mathrm{~nm}$ and $700 \mathrm{~nm}$, a millimolar extinction coefficient of $7.6 \mathrm{mM}^{-1} \mathrm{~cm}^{-1}$, the molecular weight of myoglobin $(17,000)$, and the appropriate dilution factor.

\subsection{Oxygen consumption and nitric oxide metmyoglobin reducing ability}

Steaks designated for oxygen consumption and nitric oxide reducing ability were sampled by removing a $2.54 \mathrm{~cm} \times 2.54 \mathrm{~cm} \times$ steak thickness cube from the center of the steak, taking care to avoid connective tissue and large pieces of marbling. The cube was divided in half horizontally exposing the interior of the muscle. The top half including the surface previously exposed to light and oxygen was used for nitric oxide reducing ability determination. The bottom half, including the surface never exposed to light or oxygen was used for oxygen consumption.

Oxygen consumption was initially determined by the methods described by King, Shackelford, and Wheeler (2011). The newly exposed surface was allowed to oxygenate at $4{ }^{\circ} \mathrm{C}$ for two hours while covered with previously described oxygen permeable film. The sample then was vacuum-packaged and immediately scanned with a Hunter Miniscan colorimeter with settings previously described that had been calibrated through the oxygen impermeable film of a vacuum bag. The vacuum-packaged sample was incubated for $30 \mathrm{~min}$ in a $30{ }^{\circ} \mathrm{C}$ waterbath, and scanned with the colorimeter to obtain the spectral data. Oxygen consumption was recorded as (\% OMb before - \% OMb after/\% OMb before). Initial analyses indicated that because samples with greater severity of the dark cutting condition had much lower initial (bloomed) levels of oxymyoglobin than Control samples, the percentage of oxymyoglobin deoxygenated was not comparable across dark cutting classes. This difference was likely due to increased oxygen consumption in dark cutting samples limiting the extent of oxygenation 
during the initial incubation in atmospheric conditions. Thus, the bloomed oxymyoglobin levels are reported as an indicator of oxygen consumption.

The sample for nitric oxide metmyoglobin reducing ability was oxidized in $50 \mathrm{~mL}$ of a $0.3 \%$ sodium nitrite solution for $30 \mathrm{~min}$ at approximately $20^{\circ} \mathrm{C}$ as described by AMSA (2012). The sample was removed from the solution, blotted, and vacuum packaged. Immediately after packaging, the sample was scanned in duplicate with a Hunter Miniscan colorimeter with the settings already reported. The sample was allowed to be reduced in a water bath $\left(30^{\circ} \mathrm{C}\right)$ for $2 \mathrm{~h}$, and scanned again in duplicate. Surface metmyoglobin was quantified using the equations defined by AMSA (2012). The proportion of surface metmyoglobin that was initially recorded after oxidation with nitrite was reported as initial metmyoglobin formation (IMF).

\subsection{Glycolytic potential}

Glycolytic potential determination was conducted following a modified procedure prescribed by Miller, Ellis, Sutton, McKeith, and Wilson (2000) with additional modifications (Souza et al., 2011). A $3.00 \pm$ $0.05 \mathrm{~g}$ sampled of homogenous powder was homogenized in $15.0 \mathrm{~mL}$ of $0.6 \mathrm{~N}$ perchloric acid, and $200 \mu \mathrm{L}$ of this homogenate was then transferred in duplicate into $1.5 \mathrm{~mL}$ microcentrifuge tube. One aliquot was digested with $1.0 \mathrm{~mL}$ of cold amyloglycosidase (AGS) in $0.2 \mathrm{M}$ acetate buffer $(\mathrm{pH}=4.8)$ and $20 \mu \mathrm{L} 5.4 \mathrm{~N}$ potassium hydroxide. In another $1.5 \mathrm{~mL}$ microcentrifuge tube $200 \mu \mathrm{L}$ of homogenate was incubated with $1 \mathrm{~mL}$ of $0.2 \mathrm{M}$ acetate buffer $(\mathrm{pH}=4.8)$, and $20 \mu \mathrm{L} 5.4 \mathrm{~N}$ potassium hydroxide without AGS. The AGS cleaves $\alpha(1-4)$ glycosidic linkages and $\alpha(1-6)$ glycosidic linkages in glycogen to yield glucose.

The AGS and non-AGS aliquots were then incubated at $37^{\circ} \mathrm{C}$ for $3 \mathrm{~h}$ while inverting samples every $20 \mathrm{~min}$ to thoroughly mix. After incubation, AGS and non-AGS aliquots were placed on ice and $100 \mu \mathrm{L}$ of cold $3 \mathrm{~N}$ perchloric acid was added and then centrifuged $(10,000 \times \mathrm{g})$ at $4{ }^{\circ} \mathrm{C}$ for $5 \mathrm{~min}$ to allow for pellet precipitation. Concentration of glucose was determined using a Glucose (HK) Assay Kit (Sigma-Aldrich, St. Louis, MO) on the non-AGS-digested sample. Concentration of glycogen plus glucose was determined using the same kit on the AGS digested sample. Both assays were read at $340 \mathrm{~nm}$ using a Spectramax plus 96well plate reader along with a standard curve prepared using the glucose that was supplied in the kit. The amount of glycogen was determined by the difference in the concentrations of the two assays. Lactate content was measured by incubating $20 \mu \mathrm{L}$ of the AGS digested sample in $180 \mu \mathrm{L}$ of assay buffer containing $0.2 \mathrm{M}$ glycine, $0.003 \mathrm{M} \mathrm{NAD}^{+}$, and 3 units of lactate dehyrogenase. Glycolytic potential was calculated utilizing the following formula: GP $=2[$ (glycogen $)+$ (glucose which includes glucose-6-phosphate)] + [lactate], and was expressed as lactate equivalents per g muscle (Monin \& Sellier, 1985).

\subsection{Mitochondrial isolation and mitochondrial $\mathrm{H}_{2} \mathrm{O}_{2}$ production}

Beef longissimus muscle mitochondria were isolated according to Cawthon, McNew, Beers, and Bottje (1999) and Iqbal et al. (2005) with modifications. Preliminary analyses suggested that assays conducted more than $2 \mathrm{~h}$ after extraction produced spurious results. Thus, a subset of the carcasses used in this study was selected for mitochondrial isolation and mitochondrial $\mathrm{H}_{2} \mathrm{O}_{2}$ production. Moreover, assays that exhibited a loss of fluorescence during incubation were removed from the dataset. Thus, 177 samples with data for $\mathrm{H}_{2} \mathrm{O}_{2}$ production with succinate as an energy source were used in the final analysis. A $10.0 \pm 0.10 \mathrm{~g}$ of finely minced beef longissimus muscle was added to $40 \mathrm{~mL}$ of isolation buffer (220 mM D-Mannitol, $70 \mathrm{mM}$ sucrose, $2 \mathrm{mM}$ HEPES, $0.5 \mathrm{mg} / \mathrm{mL}$ BSA, $1 \mathrm{mM}$ EGTA, pH 7.4) in a $50 \mathrm{~mL}$ conical tube, and then homogenized in an Eberbock blender on low for $10 \mathrm{~s}$, followed by further homogenization in a Potter-Elvenhjem vessel with a Teflon pestle of $0.15 \mathrm{~mm}$ clearance (Thomas Scientific, Swedesboro, NJ). A $500 \mu \mathrm{L}$ aliquot of Trypsin $(40 \mathrm{mg} / \mathrm{mL})$ was then added to the homogenized sample and then vortexed for $10 \mathrm{~s}$, followed by centrifugation $(1000 \times \mathrm{g})$ at $4{ }^{\circ} \mathrm{C}$ for $11 \mathrm{~min}$. The supernatant then was filtered through glass wool sandwiched between two layers of cheese cloth into another $50 \mathrm{~mL}$ conical tube. Again, the supernatant was centrifuged $(1000 \times g)$ for $11 \mathrm{~min}$ and then filtered, through glass wool sandwiched between two layers of cheese cloth, into a $35 \mathrm{~mL}$ centrifuge tube. The supernatant was then centrifuged $(10,000 \times \mathrm{g})$ at $4{ }^{\circ} \mathrm{C}$ for $15 \mathrm{~min}$. The resulting pellet was washed twice by resuspending the pellet in approximately $25 \mathrm{ml}$ of wash buffer (220 mM D-Mannitol, $70 \mathrm{mM}$ sucrose, $2 \mathrm{mM}$ HEPES, $0.5 \mathrm{mg} / \mathrm{mL} \mathrm{BSA}, \mathrm{pH} 7.4$ ) and centrifuging $(10,000 \times g)$ at $4{ }^{\circ} \mathrm{C}$ for $15 \mathrm{~min}$. The final pellet was resuspended in $500 \mu \mathrm{L}$ of wash buffer. Protein determination was conducted using a bicinchoninic acid (BCA) protein assay kit (Pierce; Rockford, IL. USA) with a BSA standard curve.

Mitochondrial $\mathrm{H}_{2} \mathrm{O}_{2}$ production was measured following the method of Bottje et al. (2002) with modifications. The reaction conditions for $\mathrm{H}_{2} \mathrm{O}_{2}$ measurement included the addition of $90 \mu \mathrm{g}$ of mitochondrial protein, $52 \mu \mathrm{M} 2^{\prime}-7^{\prime}$ dichlorfluorescin diacetate, $50 \mu \mathrm{L} \mathrm{H}_{2} \mathrm{O}_{2}$ buffer containing $145 \mathrm{mM} \mathrm{KCL}, 30 \mathrm{mM}$ HEPES, $5 \mathrm{mM} \mathrm{KH}_{2} \mathrm{PO}_{4}, 3 \mathrm{mM} \mathrm{MgCl}_{2}$, and $0.1 \mathrm{mM}$ EGTA ( $\mathrm{pH}=7.4$ ). Superoxide dismutase (20 units per well) was added to each well ensure that all $\mathrm{O}^{2} \cdot-$ was converted to $\mathrm{H}_{2} \mathrm{O}_{2}$. Succinate $(8 \mathrm{mM})$ provided the reducing equivalents needed for the electron transport chain. The total volume for each well was $95 \mu \mathrm{L}$. The 96 -well black microplate was placed in a Spectra MAX M5 (Molecular Devices, Sunnydale, CA) spectrophotometer set at $37{ }^{\circ} \mathrm{C}$ with excitation/emission wavelengths of $480 / 530 \mathrm{~nm}$. Fluorescence was read at 10 and $30 \mathrm{~min}$. Electron loss was determined as the percentage increase in fluorescence units.

\subsection{Mitochondrial abundance}

Relative mitochondrial abundance was determined by quantifying the relative abundance of mitochondrial and genomic DNA. Following the protocol outlined by the manufacturer, DNA was extracted from muscle samples using Promega Wizard SV 96 Genomic DNA Purification System (Promega Corp, Madison, WI). Special care was taken to ensure complete digestion of the muscle sample before isolating DNA. DNA was diluted to a final concentration of $50 \mathrm{ng} / \mu \mathrm{L}$. Mitochondrial DNA was quantified by real-time RT-PCR using previously published primers for cattle (Iwata et al., 2011) and genomic DNA was quantified using previously published primers for the follicle stimulating hormone receptor (FSHR) Marson, Ferraz, Meirelles, Baliero, and Eler (2008). Twentyfive $\mu \mathrm{L}$ reactions were run using $8.5 \mu \mathrm{L}$ of water, $12.5 \mu \mathrm{L}$ of Master Mix containing SYBR Green (Bio-Rad catalog \# 170-8893), $1.5 \mu \mathrm{L}$ of the forward primer, $1.5 \mu \mathrm{L}$ of reverse primer, and $1 \mu \mathrm{L}$ of DNA. The PCR was performed as described by (Iwata et al., 2011). Initial denaturation was for 5 min at $95^{\circ} \mathrm{C}$ followed by 40 cycles at $95^{\circ} \mathrm{C}, 58^{\circ} \mathrm{C}$, and $72^{\circ} \mathrm{C}$ for 30 s each. A melting curve was performed to check the specificity of the products. Relative amounts of mitochondrial DNA were expressed as the ratio of the threshold cycle of mitochondrial DNA to the ratio of the threshold cycle for FSHR (genomic DNA).

\subsection{Measurement of protein solubility and carbonyl determination}

Protein solubility was used as an indicator of functionality of the sarcoplasmic proteins in the muscle samples. Carbonyl content (protein oxidation) was spectrophotometrically determined to indicate the amount of oxidative damage to the sarcoplasmic protein fraction following the protocol of Keller, Halmes, Hinson, and Pumford (1993) and Reznick and Packer (1994) with modifications. A $5 \pm 0.1 \mathrm{~g}$ sample of frozen minced beef longissimus muscle was homogenized in $15 \mathrm{~mL}$ of Post Rigor Extraction buffer (100 mM Tris, 10 mM EDTA, 0.05\% 2mercaptoethanol [MCE]; $\mathrm{pH}=8.3$ ) in a $35 \mathrm{~mL}$ conical tube. Samples were then centrifuged $(27,000 \times \mathrm{g})$ for $30 \mathrm{~min}$ at $4{ }^{\circ} \mathrm{C}$ and filtered through cheesecloth. Protein determination was conducted with a $B C A$ reaction using a BSA standard curve. Protein solubility was reported 
as mg of soluble protein per gram of wet tissue. Two $1 \mathrm{~mL}$ aliquots adjusted to $6 \mathrm{mg} / \mathrm{mL}$ in $1 \mathrm{mM}$ EDTA, $50 \mathrm{mM} \mathrm{NaHPO}_{4}(\mathrm{pH}=7.4)$ were placed in $15 \mathrm{~mL}$ conical tubes. To one tube, $4 \mathrm{~mL}$ of $10 \mathrm{mM} \mathrm{2,4-}$ dinitrophenylhydrazine (DNPH) (Sigma Aldrich Inc., St. Louis, MO) in $2.5 \mathrm{M} \mathrm{HCl}$ was added while in the other tube only $4 \mathrm{~mL}$ of $2.5 \mathrm{M} \mathrm{HCl}$ solution was added. Samples were incubated for $1 \mathrm{~h}$ at room temperature in the dark with the samples being vortexed every 15 min during incubation. After incubation, $5 \mathrm{~mL}$ of $20 \%$ trichloroacetic acid (TCA) was added to both DNPH and $\mathrm{HCl}$ samples and incubated on ice for $10 \mathrm{~min}$. After incubation, samples were centrifuged $(1000 \times \mathrm{g})$ at room temperature for $7 \mathrm{~min}$ and then the supernatant was discarded. Next, $4 \mathrm{~mL}$ of $10 \%$ TCA was added to the sample, and the sample was sonicated to ensure that the sample was completely solubilized. Following sonication, samples were centrifuged $(1000 \times g)$ at room temperature for $7 \mathrm{~min}$ and then the supernatant was discarded. For both tubes, the sample pellet was then washed three times in a mixture of ethanol/ethyl acetate ( $1: 1$ by volume) followed by sonication and then centrifugation $(1000 \times g)$ for $7 \mathrm{~min}$ at room temperature. The precipitated protein pellet was then re-dissolved in $2 \mathrm{~mL}$ of $6 \mathrm{M}$ guanidine hydrochloride (Sigma Aldrich Inc., St. Louis, MO) and incubated at $37^{\circ} \mathrm{C}$ for $10 \mathrm{~min}$.

Protein determination was conducted with a BCA reaction using a BSA standard curve. Carbonyl content was calculated by obtaining the a reading at $360 \mathrm{~nm}$ for the DNPH-treated samples and these samples were scanned against the samples treated with $2.5 \mathrm{M} \mathrm{HCl}$ on a DU640 spectrophotometer (Beckman Coulter Inc., Fullerton, CA). The protein carbonyl content ( $\mathrm{nmol} / \mathrm{mg}$ protein) was calculated using the molar extinction coefficient for DNPH is $22,000 \mathrm{M}^{-1} \mathrm{~cm}^{-1}$ and the following formula: protein carbonyl content $=($ absorbance $\times 106 / 22,000) / \mathrm{mg}$ protein.

\subsection{Statistical analysis}

Data were analyzed as a randomized complete block design using the PROC GLIMMIX procedure of SAS (SAS Inst., Inc., Cary, NC) comparing dark cutting severity classes to normal cohorts. Selection day was included as a block. Initial analyses indicated that the individual Control groups were similar $(P>0.05)$ with regard to all of the traits measured in the experiment. Thus, data from Control carcasses were pooled together for comparisons with the various dark cutter classes. Least squares means for dark cutter classes were generated with the LSMEANS statement. When F-tests indicated that dark cutting classifications differed for a trait, means were separated using the DIFF and LINES options on the LSMEANS statement.

Color stability data collected during simulated retail display were analyzed as described above with the addition of day of display and its square and cube as covariates. The squared day of display term was added to all models. Day of display cubed was added when lack-of-fit tests indicated quadratic models were not sufficient to describe the trends in color change. Regression equations were generated for the change in color parameters during simulated retail display using contrasts to calculate the day 0 values (intercept) and $\beta$-coefficients describing the change during simulate retail display. When F-tests indicated these values differed across dark cutting classifications, pair-wise comparisons were made using orthogonal contrasts. A level of 0.05 was used to determine differences between dark cutter classes and the pooled normal cohort group.

\section{Results and discussion}

Least squares means for glycolytic status and muscle $\mathrm{pH}$ of longissimus lumborum steaks from carcasses from each of the dark cutter classifications are presented in Table 1 . Carcasses were visually identified as dark cutters by trained evaluators at grading and then classified by severity within each selection day by muscle $\mathrm{pH}$ as measured at grading. Thus, by definition, muscle $\mathrm{pH}$ increased $(P<0.05)$
Table 1

Least squares means (standard error) for glycolytic status and muscle $\mathrm{pH}$ of longissimus lumborum from carcasses classified by dark cutting severity.

\begin{tabular}{lcccc}
\hline $\begin{array}{l}\text { Dark cutter } \\
\text { classification }\end{array}$ & $\begin{array}{l}\text { Ultimate } \\
\mathrm{pH}^{1}\end{array}$ & $\begin{array}{l}\text { Glycolytic } \\
\text { potential, } \mu \mathrm{mol} / \mathrm{g}^{2}\end{array}$ & $\begin{array}{l}\text { Glycogen, } \\
\mu \mathrm{mol} / \mathrm{g}\end{array}$ & $\begin{array}{l}\text { Lactate, } \\
\mu \mathrm{mol} / \mathrm{g}\end{array}$ \\
\hline Control $^{3}$ & 5.7 & $149.73^{\mathrm{a}}$ & $30.39^{\mathrm{a}}$ & $88.94^{\mathrm{a}}$ \\
& $(0.02)$ & $(3.50)$ & $(0.97)$ & $(1.87)$ \\
Shady $^{4}$ & 6.1 & $81.68^{\mathrm{b}}$ & $4.97^{\mathrm{b}}$ & $71.72^{\mathrm{b}}$ \\
& $(0.03)$ & $(4.62)$ & $(1.55)$ & $(2.35)$ \\
Mild $^{5}$ & 6.4 & $69.12^{\mathrm{c}}$ & $3.11^{\mathrm{b}}$ & $63.25^{\mathrm{c}}$ \\
& $(0.03)$ & $(4.72)$ & $(1.58)$ & $(2.36)$ \\
Moderate $^{6}$ & 6.6 & $56.64^{\mathrm{d}}$ & $1.84^{\mathrm{b}}$ & $53.17^{\mathrm{d}}$ \\
& $(0.03)$ & $(4.76)$ & 1.62 & $(2.38)$ \\
Severe $^{7}$ & 6.9 & $44.69^{\mathrm{e}}$ & $1.36^{\mathrm{b}}$ & $41.93^{\mathrm{e}}$ \\
& $(0.03)$ & $(4.65)$ & $(1.56)$ & $(2.36)$ \\
$\mathrm{P}>\mathrm{F}$ & $<0.001$ & $<0.001$ & $<0.001$ & $<0.001$ \\
\hline
\end{tabular}

abcde Least squares means, within a column, lacking common superscripts, $\operatorname{differ}(P<0.05)$.

1 Muscle $\mathrm{pH}$ measured in longissimus lumborum approximately $36 \mathrm{~h}$ postmortem after carcasses were presented for grading.

2 Expressed as lactate equivalents (i.e.) each glucose molecule is equivalent to 2 lactate molecules.

${ }^{3} \mathrm{n}=160$.

${ }^{4} \mathrm{n}=40$.

$5 \mathrm{n}=40$.

${ }^{6} \mathrm{n}=40$

${ }^{7} \mathrm{n}=40$.

as dark cutting severity class increased. Page, Wulf, and Schwotzer (2001) evaluated 1000 beef carcasses, $80 \%$ of which were within the $\mathrm{pH}$ range of 5.40 to 5.59 , which is deemed a normal $\mathrm{pH}$ for the beef longissimus lumborum undergoing postmortem metabolism (Lawrie, 1958; Tarrant \& Mothersill, 1977). However, the mean normal (cohort) $\mathrm{pH}$ (5.65) observed in this experiment was greater than the maximum of that range. Additionally, Page et al. (2001) reported that dark cutting carcasses had a pH range of 5.87 to 6.89 . The mean $\mathrm{pH}$ (6.89) of the Severe dark cutting carcasses in the present experiment was the same as the upper end of the range observed by Page et al. (2001) and the maximum pH observed in this study was much greater (7.29).

Glycolytic potential is a measurement of the amount of glycogen and lactate present in muscle as an indicator of the glycogen that was present in the living muscle that could potentially be converted to lactate, consequently, driving the ultimate $\mathrm{pH}$ of meat. In the present experiment, glycolytic potential was highest $(P<0.05)$ in longissimus lumborum steaks from the carcasses with normal lean color and decreased $(P<0.05)$ progressively as dark cutting severity increased. As expected, postmortem lactate content differences across dark cutter classes mirrored those in glycolytic potential.

The relationships between ultimate $\mathrm{pH}$ and glycolytic potential, residual glycogen, and lactate are presented in Fig. 1. In the present study, the relationship between glycolytic potential and ultimate $\mathrm{pH}$ was curvilinear. Fitting a quadratic equation for the relationship between glycolytic potential and ultimate $\mathrm{pH}$ resulted in the equation: Ultimate $\mathrm{pH}=7.44-0.019 \times$ glycolytic potential $+0.000050 \times$ glycolytic potential squared $\left(P<0.001 ; \mathrm{R}^{2}=0.85\right)$. A glycolytic potential of approximately $100 \mu \mathrm{mol} / \mathrm{g}$ of tissue was required to achieve ultimate $\mathrm{pH}$ values below 6.0. Moreover, the impact of increasing glycolytic potential beyond approximately $130 \mu \mathrm{mol} / \mathrm{g}$, which corresponds to a predicted ultimate $\mathrm{pH}$ value of 5.76, had little effect on ultimate $\mathrm{pH}$ values. This suggests that when glycogen levels are not the limiting factor, postmortem glycolysis, and thus, $\mathrm{pH}$ decline is halted by other factors. Correspondingly, residual glycogen levels were very small in longissimus lumborum samples with ultimate pH greater than 5.7 (Fig. 1, panel B). Moreover, the maximum lactate level observed in the present experiment was $104 \mu \mathrm{mol} / \mathrm{g}$. These data suggest that perimortem muscle can convert approximately $50 \mu \mathrm{mol} / \mathrm{g}$ (equivalent to $100 \mu \mathrm{mol} / \mathrm{g}$ lactate) of glycogen and glucose to lactate before glycolysis is halted by factors other than substrate depletion.

Glycolytic potential assumes all glycogen is converted to lactate during the conversion of muscle to meat. However, residual glycogen 

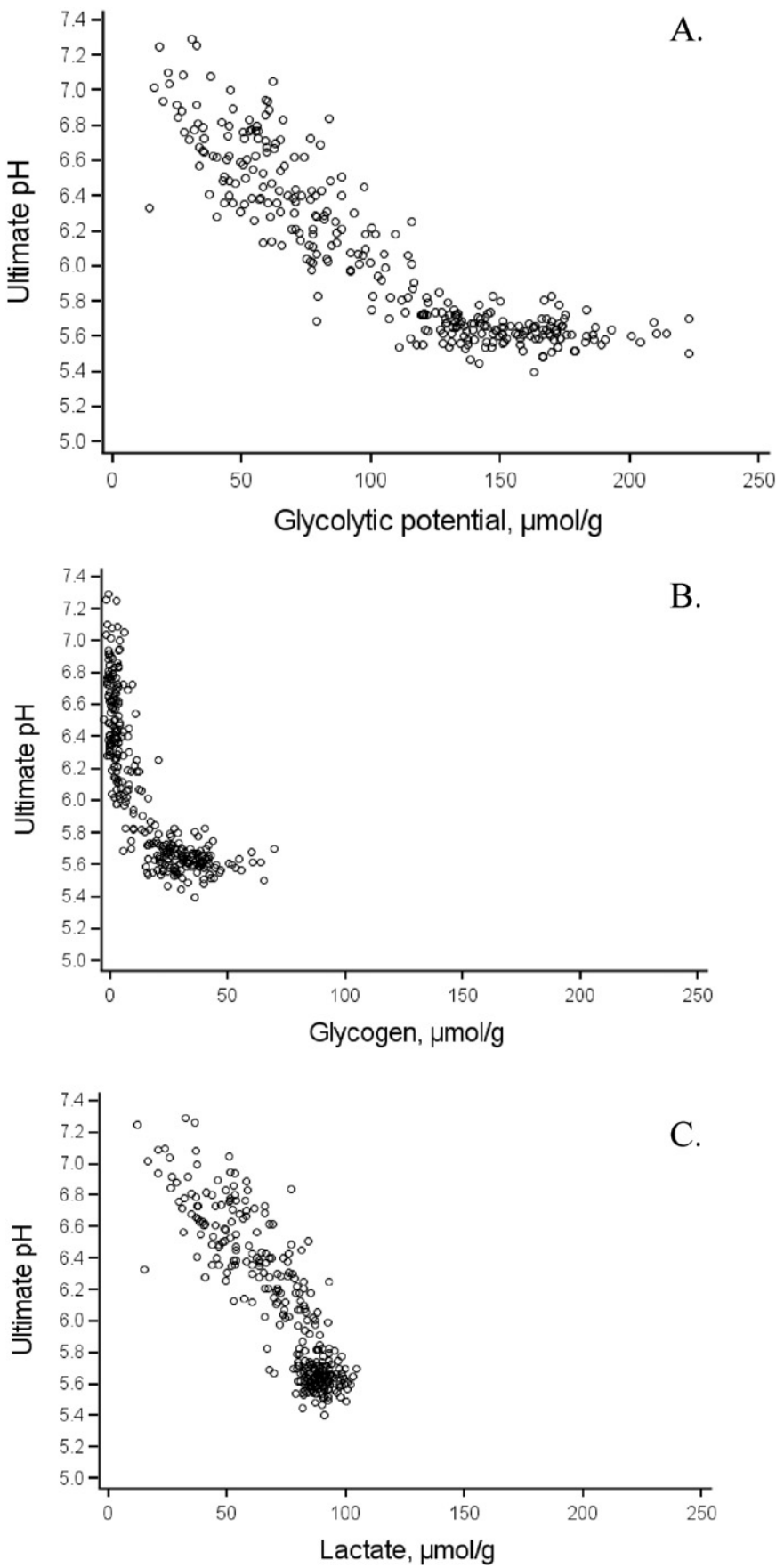

Fig. 1. Plots of Ultimate $\mathrm{pH}$ as a function of glycolytic potential (Panel A), residual glycogen (Panel B), and lactate (Panel C) in longissimus lumborum steaks from beef carcasses exhibiting varying degrees of the dark cutting condition and normal controls from the same production lots.

is present, even in the dark cutting classes. Rhoades et al. (2005) and England, Matarneh, Scheffler, Wachet, and Gerrard (2014) reported that the phosphofructokinase enzyme (PFK) was $\mathrm{pH}$ sensitive and that as $\mathrm{pH}$ decreased, PFK activity was drastically reduced and the enzyme kinetics indicated a loss of cooperativity. Thus, it appears that loss of PFK function, rather than substrate depletion, is the limiting factor of $\mathrm{pH}$ decline in beef carcasses with normal amounts of glycogen. Residual glycogen content was much greater in steaks from carcasses exhibiting normal lean color compared to those displaying the dark cutting condition $(P<0.05)$. Glycogen content did not differ $(P<0.05)$ among the dark cutter severity classes, although the numeric values of the means did decrease as dark cutting severity increased. Levels of residual glycogen in Control carcasses were consistent with the residual glycogen reported by Rhoades et al. (2005). Hanson, Kirchofer, and Calkins (2001) reported similar residual muscle glycogen levels in longissimus lumborum carcasses exhibiting normal lean color, but reported residual muscle glycogen levels in longissimus lumborum from dark cutting carcasses that were much greater than those found in the present experiment.

Wulf et al. (2002) reported that carcasses with glycolytic potential values below approximately $100 \mu \mathrm{mol} / \mathrm{g}$ had higher muscle $\mathrm{pH}$ values because the glycogen stores found in the muscle tissue were depleted. In regards to muscle glycogen levels, Hanson et al. (2001) reported that dark cutting conditions were more likely to occur in carcasses when muscle glycogen concentrations are less than $80 \mathrm{mmol} / \mathrm{kg}$.

Lean color characteristics of the longissimus thoracis of carcasses in each of the dark cutting classes measured after grading are presented in Table 2. Muscle lightness $\left(\mathrm{L}^{*}\right)$ was greatest $(P<0.05)$ in the carcasses from the Control class and lowest $(P<0.05)$ in the longissimus lumborum of the carcasses from the Moderate and Severe dark cutting classes. Lightness of the longissimus lumborum from carcasses in the Shady and Mild dark cutter classes were intermediate. Redness of the 12th rib longissimus thoracis cross section was greater in Control carcasses than in carcasses from the Shady dark cutter class, which was greater than in Mild dark cutting class carcasses. Redness ( $a^{*}$ ) was least $(P<0.05)$ in Moderate and Severe dark cutting class carcasses. The same trend across dark cutting classifications was detected for $b^{*}$, and chroma (color intensity) values. Hue angle values decreased $(P<0.05)$ with each increase in dark cutting severity.

Coefficients for regression equations describing the change in color parameters of the steaks from carcasses in each of the dark cutter classes are presented in Table 3. The intercept estimates indicate that on day 0 of display, longissimus lumborum steaks from Control carcasses were lighter $(P<0.05)$ than longissimus lumborum steaks from the other dark cutter classes. Overall, $L^{*}$ values of longissimus lumborum steaks from carcasses of the Control class declined slightly during the $11 \mathrm{~d}$ of simulated retail display. Lightness of the longissimus lumborum steaks from carcasses in the dark cutting classes increased slightly through the first 4 days of display and then decreased to a point slightly lower than day 0 values.

On day 0 of display, a* values of longissimus lumborum steaks were greatest $(P<0.05)$ in carcasses from the Control class and least $(P<0.05)$ in carcasses from the Severe and Moderate dark cutter classes. Steaks from carcasses in the Shady dark cutter class had greater $(P<0.05)$ than those from carcasses in the Mild dark cutter class, which did not differ $(P>0.05)$ from those in the Moderate dark cutter class. Coefficients describing the change in $a^{*}$ during simulated retail display were similar among the dark cutter classes, which were

Table 2

Least squares means (standard error) for color traits of longissimus thoracis from carcasses classified by dark cutting severity after grading.

\begin{tabular}{llllll}
\hline Dark cutter classification & $\mathrm{L}^{*}$ & $\mathrm{a}^{*}$ & $\mathrm{~b}^{*}$ & Hue angle & Chroma \\
\hline Control $^{1}$ & $42.8^{\mathrm{a}}$ & $30.4^{\mathrm{a}}$ & $22.4^{\mathrm{a}}$ & $33.3^{\mathrm{a}}$ & $37.8^{\mathrm{a}}$ \\
& $(0.83)$ & $(0.37)$ & $(0.46)$ & $(0.28)$ & $(0.56)$ \\
Shady $^{2}$ & $38.0^{\mathrm{b}}$ & $27.0^{\mathrm{b}}$ & $19.0^{\mathrm{b}}$ & $32.2^{\mathrm{b}}$ & $33.0^{\mathrm{b}}$ \\
& $(0.96)$ & $(0.55)$ & $(0.63)$ & $(0.34)$ & $(0.81)$ \\
Mild $^{3}$ & $37.1^{\mathrm{b}}$ & $25.5^{\mathrm{c}}$ & $17.4^{\mathrm{c}}$ & $31.3^{\mathrm{c}}$ & $30.9^{\mathrm{c}}$ \\
& $(0.96)$ & $(0.55)$ & $(0.63)$ & $(0.34)$ & $(0.81)$ \\
Moderate $^{4}$ & $35.0^{\mathrm{c}}$ & $23.5^{\mathrm{d}}$ & $15.3^{\mathrm{d}}$ & $30.3^{\mathrm{d}}$ & $28.1^{\mathrm{d}}$ \\
& $(0.96)$ & $(0.55)$ & $(0.63)$ & $(0.34)$ & $(0.81)$ \\
Severe $^{5}$ & $34.8^{\mathrm{c}}$ & $22.4^{\mathrm{d}}$ & $14.1^{\mathrm{d}}$ & $29.5^{\mathrm{e}}$ & $26.5^{\mathrm{d}}$ \\
& $(0.96)$ & $(0.55)$ & $(0.63)$ & $(0.34)$ & $(0.81)$ \\
P $>\mathrm{F}$ & $<0.001$ & $<0.001$ & $<0.001$ & $<0.001$ & $<0.001$
\end{tabular}

abcde Least squares means, within a column, lacking common superscripts, differ $(P<0.05)$.

$1 \mathrm{n}=160$

$2 \mathrm{n}=40$.

${ }^{3} \mathrm{n}=40$.

$4 \mathrm{n}=40$.

$5 \mathrm{n}=40$. 
Table 3

Regression coefficients for the change in color variables during simulated retail display in longissimus lumborum steaks from carcasses classified by dark cutter severity.

\begin{tabular}{|c|c|c|c|c|}
\hline Dark cutter classification & $\beta_{0}^{1}$ & $\beta_{1}{ }^{2}$ & $\beta_{2}{ }^{3}$ & $\beta_{3}{ }^{4}$ \\
\hline \multicolumn{5}{|l|}{$\mathrm{L}^{*}$} \\
\hline \multirow[t]{2}{*}{ Control $^{5}$} & $44.63^{\mathrm{a}}$ & $-0.55^{\mathrm{b}}$ & $0.08^{\mathrm{a}}$ & $-0.006^{\mathrm{b}}$ \\
\hline & $(0.91)$ & $(0.19)$ & $(0.05)$ & $(0.003)$ \\
\hline \multirow[t]{2}{*}{ Shady $^{6}$} & $35.46^{\mathrm{b}}$ & $0.51^{\mathrm{a}}$ & $-0.12^{\mathrm{ab}}$ & $0.004^{\mathrm{ab}}$ \\
\hline & $(1.04)$ & $(0.38)$ & $(0.09)$ & $(0.006)$ \\
\hline \multirow[t]{2}{*}{ Mild $^{7}$} & $33.63^{b}$ & $0.30^{\mathrm{a}}$ & $-0.09^{\mathrm{ab}}$ & $0.003^{\mathrm{ab}}$ \\
\hline & $(1.04)$ & $(0.38)$ & $(0.09)$ & $(0.006)$ \\
\hline \multirow[t]{2}{*}{ Moderate $^{8}$} & $31.53^{b}$ & $0.65^{\mathrm{a}}$ & $-0.18^{\mathrm{b}}$ & $0.010^{\mathrm{a}}$ \\
\hline & $(1.04)$ & $(0.39)$ & $(0.09)$ & $(0.006)$ \\
\hline \multirow[t]{2}{*}{ Severe $^{9}$} & $30.24^{\mathrm{b}}$ & $1.29^{\mathrm{a}}$ & $-0.32^{\mathrm{b}}$ & $0.017^{a}$ \\
\hline & $(1.04)$ & $(0.39)$ & $(0.09)$ & $(0.006)$ \\
\hline$P>\mathrm{F}$ & $<.0001$ & $<.0001$ & 0.0008 & 0.0015 \\
\hline \multicolumn{5}{|l|}{$a^{*}$} \\
\hline \multirow[t]{2}{*}{ Control $^{5}$} & $35.63^{\mathrm{a}}$ & $-1.64^{\mathrm{b}}$ & $0.25^{\mathrm{a}}$ & $-0.0218^{b}$ \\
\hline & $(0.57)$ & $(0.22)$ & $(0.05)$ & $(0.003)$ \\
\hline \multirow[t]{2}{*}{ Shady $^{6}$} & $29.87^{b}$ & $0.78^{\mathrm{a}}$ & $-0.08^{\mathrm{b}}$ & $-0.0031^{\mathrm{a}}$ \\
\hline & $(0.78)$ & $(0.43)$ & $(0.10)$ & $(0.006)$ \\
\hline \multirow[t]{2}{*}{ Mild $^{7}$} & $27.20^{c}$ & $0.82^{\mathrm{a}}$ & $-0.10^{\mathrm{b}}$ & $0.0004^{a}$ \\
\hline & $(0.78)$ & $(0.43)$ & $(0.10)$ & $(0.006)$ \\
\hline \multirow[t]{2}{*}{ Moderate $^{8}$} & $25.13^{\mathrm{cd}}$ & $1.11^{\mathrm{a}}$ & $-0.15^{\mathrm{b}}$ & $0.0048^{\mathrm{a}}$ \\
\hline & $(0.78)$ & $(0.44)$ & $(0.11)$ & $(0.006)$ \\
\hline Severe $^{9}$ & $23.94^{d}$ & $1.96^{\mathrm{a}}$ & $-0.31^{b}$ & $0.0128^{\mathrm{a}}$ \\
\hline & $(0.79)$ & $(0.44)$ & $(0.11)$ & $(0.006)$ \\
\hline$P>\mathrm{F}$ & $<.0001$ & $<.0001$ & $<.0001$ & $<.0001$ \\
\hline$b^{*}$ & & & & \\
\hline Control $^{5}$ & $27.56^{\mathrm{a}}$ & $-0.39^{\mathrm{b}}$ & $-0.03^{a}$ & - \\
\hline & $(0.58)$ & $(0.09)$ & $(0.01)$ & - \\
\hline Shady ${ }^{6}$ & $22.21^{b}$ & $1.18^{\mathrm{a}}$ & $-0.13^{b}$ & - \\
\hline & $(0.69)$ & $(0.18)$ & $(0.02)$ & - \\
\hline Mild $^{7}$ & $19.35^{c}$ & $1.18^{a}$ & $-0.12^{b}$ & - \\
\hline & $(0.69)$ & $(0.18)$ & $(0.02)$ & - \\
\hline Moderate $^{8}$ & $17.24^{\mathrm{d}}$ & $1.29^{\mathrm{a}}$ & $-0.11^{\mathrm{b}}$ & - \\
\hline & $(0.69)$ & $(0.19)$ & $(0.02)$ & - \\
\hline Severe $^{9}$ & $16.04^{d}$ & $1.67^{a}$ & $-0.14^{\mathrm{b}}$ & - \\
\hline & $(0.69)$ & $(0.19)$ & $(0.02)$ & - \\
\hline$P>\mathrm{F}$ & $<.0001$ & $<.0001$ & $<.0001$ & - \\
\hline Hue angle & & & & \\
\hline Control $^{5}$ & $35.06^{\mathrm{a}}$ & $-0.54^{\mathrm{d}}$ & $0.12^{\mathrm{a}}$ & - \\
\hline & (0.39) & $(0.08)$ & $(0.01)$ & - \\
\hline Shady ${ }^{6}$ & $33.51^{b}$ & $0.49^{c}$ & $-0.03^{b}$ & - \\
\hline & $(0.57)$ & $(0.15)$ & $(0.01)$ & - \\
\hline Mild $^{7}$ & $32.38^{b c}$ & $0.72^{\mathrm{bc}}$ & $-0.05^{b}$ & - \\
\hline & $(0.56)$ & $(0.15)$ & $(0.01)$ & - \\
\hline Moderate $^{8}$ & $31.30^{\mathrm{cd}}$ & $1.03^{\mathrm{ab}}$ & $-0.08^{\mathrm{bc}}$ & - \\
\hline & $(0.57)$ & $(0.16)$ & $(0.01)$ & - \\
\hline Severe $^{9}$ & $30.38^{d}$ & $1.32^{\mathrm{a}}$ & $-0.11^{\mathrm{c}}$ & - \\
\hline & $(0.57)$ & $(0.16)$ & $(0.01)$ & - \\
\hline$P>\mathrm{F}$ & $<.0001$ & $<.0001$ & $<.0001$ & - \\
\hline Chroma & & & & \\
\hline Control $^{5}$ & $44.85^{\mathrm{a}}$ & $-0.55^{\mathrm{b}}$ & $-0.09^{a}$ & - \\
\hline & $(0.78)$ & $(0.14)$ & $(0.01)$ & - \\
\hline Shady ${ }^{6}$ & $37.22^{b}$ & $1.47^{a}$ & $-0.18^{b}$ & - \\
\hline & $(0.99)$ & $(0.28)$ & $(0.02)$ & - \\
\hline Mild $^{7}$ & $33.37^{c}$ & $1.38^{a}$ & $-0.15^{b}$ & - \\
\hline & (0.99) & $(0.28)$ & $(0.02)$ & - \\
\hline Moderate $^{8}$ & $30.51^{d}$ & $1.43^{a}$ & $-0.13^{a b}$ & - \\
\hline & $(1.00)$ & $(0.29)$ & $(0.02)$ & - \\
\hline Severe $^{9}$ & $28.94^{\mathrm{d}}$ & $1.95^{a}$ & $-0.17^{b}$ & - \\
\hline & $(1.00)$ & $(0.29)$ & $(0.02)$ & - \\
\hline$P>\mathrm{F}$ & $<.0001$ & $<.0001$ & 0.0028 & - \\
\hline$\Delta \mathrm{E}$ & & & & \\
\hline Control $^{5}$ & 1.61 & $0.37^{\mathrm{b}}$ & $0.11^{\mathrm{a}}$ & - \\
\hline & $(0.56)$ & $(0.13)$ & $(0.01)$ & - \\
\hline Shady $^{6}$ & 1.90 & $0.50^{\mathrm{b}}$ & $0.01^{\mathrm{b}}$ & - \\
\hline & $(0.68)$ & $(0.26)$ & $(0.02)$ & - \\
\hline Mild $^{7}$ & 1.76 & $0.61^{\mathrm{b}}$ & $-0.02^{\mathrm{b}}$ & - \\
\hline & $(0.68)$ & $(0.26)$ & $(0.02)$ & - \\
\hline Moderate $^{8}$ & 1.88 & $0.91^{\mathrm{ab}}$ & $-0.06^{\mathrm{b}}$ & - \\
\hline & $(0.69)$ & $(0.26)$ & $(0.02)$ & - \\
\hline Severe $^{9}$ & 1.86 & $1.62^{\mathrm{a}}$ & $-0.13^{c}$ & - \\
\hline & (0.69) & $(0.26)$ & $(0.02)$ & - \\
\hline
\end{tabular}

Table 3 (continued)

\begin{tabular}{l} 
Dark cutter classification $\beta_{0}{ }^{1} \quad \beta_{1}{ }^{2}$ \\
\hline$P>$ F
\end{tabular}

different $(P<0.05)$ from those describing change in the Control carcasses. Whereas longissimus lumborum steaks from Control carcasses displayed a gradual decrease in $a^{*}$ values during the first 7 days of simulated retail display, followed by a more rapid decrease through the end of the display period, redness increased slightly in longissimus lumborum steaks from carcasses in the Shady, Mild, Moderate, and Severe dark cutter classes during the first 5 days of display before declining to a point similar to the day 0 values. Results pertaining to $b^{*}$ values were similar to those discusses for $a^{*}$ values.

Values for hue angle on day 0 of display were greatest $(P<0.05)$ in longissimus lumborum steaks from Control carcasses. Day 0 hue angle values were greater $(P<0.05)$ in longissimus lumborum steaks from the Shady dark cutter classification than the Moderate and Severe dark cutter classes. Steaks from the Mild dark cutter classification had higher $(P<0.05)$ hue angle values than those from the Severe dark cutter classification. Although statistical differences were detected in the $\beta$-coefficients describing change in hue angle in among steaks from the Shady, Mild, Moderate, and Severe dark cutter classes, hue angle changed very little in these classes during simulated retail display and, thus, these differences were likely of little practical importance. In longissimus lumborum steaks from the Control carcasses, hue angle was stable until day 6 of display and then increased rapidly.

On day 0 of display, chroma was much greater $(P<0.05)$ in longissimus lumborum steaks from Control carcasses than in steaks from all of the other dark classes. The ranking of the remaining dark cutter classes for chroma was Shady $>$ Mild $>$ Moderate $=$ Severe. In longissimus lumborum steaks from Control carcasses, chroma decreased throughout the simulated retail display period and on day 11 of display, was lower than in longissimus lumborum steaks of the other dark cutter classes. In all of the other dark cutter classes, Chroma increased slightly during the first half of the display period and then decreased slightly during the last half of the display period. Overall color change $(\Delta \mathrm{E})$ increased during display in longissimus lumborum steaks from Control carcasses, and the rate of change increased as the time in display increased. Overall color change increased much more slowly in longissimus lumborum steaks from carcasses in the Mild and Moderate dark cutter classes. Color change in longissimus lumborum steaks from Shady dark cutter carcasses was similar to the change observed in the steaks from Mild and Moderate dark cutter carcasses through the first 7 days of display, after which the color change in longissimus lumborum steaks from Shady dark cutter carcasses was much more rapid. In longissimus lumborum steaks of Severe dark cutter carcasses, color change relative to day 0 values increased for the first 6 days of display and then decreased through the rest of the display period.

Protein solubility did not differ across dark cutting classes $(P>0.05)$, and all dark cutting severity classes had greater $(P<0.05)$ protein solubility than the Control carcasses (Table 4). The amount of soluble 
protein in the sarcoplasmic fraction that can be extracted can be used as an indication of the amount of denaturation that has occurred in muscle tissue. Joo, Kauffman, Kim, and Park (1999) reported in pork that protein solubility increases with increasing ultimate $\mathrm{pH}$.

Mitochondrial abundance was greater $(P<0.05)$ in longissimus lumborum steaks from Severe dark cutting carcasses than in longissimus lumborum from Moderate dark cutting carcasses, which had greater $(P<0.05)$ mitochondrial abundance than longissimus lumborum of Mild dark cutting carcasses. Mild dark cutting carcasses had greater $(P<0.05)$ mitochondrial abundance than longissimus lumborum steaks from Control carcasses. Ashmore, Doerr, Foster, and Carrol (1971) found no significant differences in mitochondrial protein recovered, specific gravity of mitochondrial succinate dehydrogenase, or respiratory control ratios between mitochondria from Control muscles and muscles injected with epinephrine to induce dark cutting. It must be noted that Ashmore et al. (1971) induced dark cutting by administering epinephrine, whereas the dark cutting studied in the present experiment occurred naturally.

Myoglobin concentration was highest $(P<0.05)$ in the longissimus lumborum steaks from carcasses in the Shady, Mild, and Moderate dark cutting classes. Steaks from carcasses in the Moderate dark cutting classes had greater myoglobin concentration than longissimus lumborum steaks from Control carcasses with the myoglobin concentration of longissimus lumborum steaks from Severe dark cutting carcasses being intermediate. Hunt and Hedrick (1977) reported that dark cutting carcasses had greater myoglobin concentrations than normal carcasses, and suggested that this could be a result of uncontrolled vasodilatation when animals undergo stressful conditions, thus resulting in blood pooling within the muscle. However, greater mitochondrial abundance coupled with greater myoglobin concentration in longissimus lumborum steaks from dark cutting carcasses in the present experiment suggests that animals predisposed to the dark cutting condition have greater oxidative capacity. It is not clear whether this greater oxidative capacity is a function of a shift towards red muscle fibers in carcasses affected by the dark cutting condition. Another explanation may be that the increased mitochondrial abundance and myoglobin concentration is an adaptive response to the inefficiency of the mitochondrial function.

Previous work has identified site-specific defects in the electron transport chain resulting in electron loss during respiration (Bottje et al., 2002; Iqbal et al., 2004; Ojano-Dirain et al., 2004). Measurements of electron loss were greater $(P<0.05)$ for longissimus lumborum steaks from carcasses in all dark cutter classes than in longissimus lumborum steaks from carcasses in the Control class (Table 4). Loss of electrons during electron transport has been associated with decreased feed efficiency in chickens(Bottje et al., 2002), cattle (Kolath, Kerley, Golden, \& Keisler, 2006), and pigs (Grubbs et al., 2013).

It must be noted that succinate is a substrate which enters the electron transport chain at Complex II (Bottje et al., 2002). Thus, the role of Complex I of the electron transport chain in relation to the dark cutting condition cannot be assessed from the present experiment. Moreover, the location of the defects resulting in inefficiencies leading to the dark cutting condition cannot be ascertained from the present experiment. Further investigation of the electron transport chain with various substrates and inhibitors in samples from dark cutting and normal beef samples to identify the specific locations of defects contributing to the dark cutting condition is warranted.

Perhaps the inefficiencies in energy production during electron transport exhibited by animals with site specific defects also contribute to the dark cutting condition. During times of stress, glycogen stores are mobilized to meet increased energy demands. We speculate that animals with a greater number of less efficient mitochondria would ultimately mobilize a greater proportion of their glycogen stores during times of stress than animals with more efficient mitochondria.

Because the electrons lost during electron transport result in the formation of reactive oxygen species, it was thought that longissimus lumborum steaks with mitochondria possessing these defects might have greater oxidative damage than those not possessing those defects. Thus, protein carbonyls were quantified in the sarcoplasmic fraction of the steaks. Protein carbonyl levels did not differ $(P>0.05)$ across dark cutting classes. It has been reported that metabolic factors associated with muscle tissue give rise to the formation of reactive oxygen species, thus resulting in carbonyl formation, and decreased sulfhydryl content of the proteins (Hoffman \& Hamm, 1978; Martinaud et al., 1997; Xiong, 2000).

The drastic differences in lean color between the dark cutting classes precluded the use of the methods for determining oxygen consumption and nitric oxide metmyoglobin reducing ability of intact or ground meat described by AMSA (2012) because the initial levels of oxymyoglobin and metmyoglobin in the sample (the initial measurements in the calculations for oxygen consumption and nitric oxide metmyoglobin

Table 4

Least squares means (standard error) for biochemical traits of longissimus lumborum from carcasses classified by dark cutting severity.

\begin{tabular}{|c|c|c|c|c|c|c|c|}
\hline $\begin{array}{l}\text { Dark cutter } \\
\text { classification }\end{array}$ & Protein solubility, \% & $\begin{array}{l}\text { Mitochondrial } \\
\text { abundance }^{1}\end{array}$ & Myoglobin, mg/g & $\begin{array}{l}\text { Protein carbonyls }{ }^{2} \text {, } \\
\mu \mathrm{mol} / \mathrm{mg}\end{array}$ & Electron loss ${ }^{3}$ & Bloomed $\mathrm{OMb}^{4}, \%$ & Initial $\mathrm{MMb}^{5}, \%$ \\
\hline \multirow[t]{2}{*}{ Control $^{6}$} & $21.12^{\mathrm{b}}$ & $0.60^{\mathrm{d}}$ & $4.36^{c}$ & 2.18 & $11.02^{\mathrm{b}}$ & $91.54^{\mathrm{a}}$ & $70.60^{\mathrm{a}}$ \\
\hline & $(0.48)$ & $(0.01)$ & $(0.10)$ & $(0.17)$ & $(5.35)$ & $(1.08)$ & $(0.93)$ \\
\hline \multirow[t]{2}{*}{ Shady $^{7}$} & $22.77^{a}$ & $0.60^{\mathrm{cd}}$ & $4.78^{a}$ & 2.30 & $19.91^{a}$ & $79.56^{\mathrm{b}}$ & $59.47^{b}$ \\
\hline & $(0.56)$ & $(0.01)$ & $(0.14)$ & $(0.24)$ & $(5.97)$ & $(1.40)$ & $(1.07)$ \\
\hline \multirow[t]{2}{*}{ Mild $^{8}$} & $23.43^{a}$ & $0.61^{\mathrm{c}}$ & $4.91^{\mathrm{a}}$ & 2.20 & $18.33^{a}$ & $72.97^{c}$ & $55.78^{c}$ \\
\hline & $(0.56)$ & $(0.01)$ & $(0.14)$ & $(0.24)$ & $(6.00)$ & $(1.40)$ & $(1.07)$ \\
\hline \multirow[t]{2}{*}{ Moderate $^{9}$} & $22.91^{a}$ & $0.63^{\mathrm{b}}$ & $4.68^{\mathrm{ab}}$ & 2.21 & $17.84^{\mathrm{a}}$ & $67.07^{d}$ & $51.25^{d}$ \\
\hline & $(0.56)$ & $(0.01)$ & $(0.14)$ & $(0.24)$ & $(5.89)$ & $(1.40)$ & $(1.07)$ \\
\hline \multirow[t]{2}{*}{ Severe $^{10}$} & $22.94^{a}$ & $0.64^{a}$ & $4.46^{\mathrm{bc}}$ & 2.60 & $18.66^{a}$ & $63.25^{\mathrm{e}}$ & $49.35^{e}$ \\
\hline & $(0.56)$ & $(0.01)$ & $(0.14)$ & $(0.24)$ & $(5.85)$ & $(1.40)$ & $(1.07)$ \\
\hline$P>F$ & $<0.001$ & $<0.001$ & $<0.001$ & 0.38 & 0.007 & $<0.001$ & $<0.001$ \\
\hline
\end{tabular}

abcde Least squares means, within a column, lacking common superscripts, differ $(P<0.05)$.

1 Ratio of abundance of mitochondrial DNA to abundance of genomic DNA detected by real-time PCR.

2 Carbonyls detected in the sarcoplasmic fraction.

3 Electrons lost during incubation with succinate as an energy substrate. Reactive oxygen species were converted to $\mathrm{H}^{2} \mathrm{O}^{2}$. Data are expressed as the percentage increase in flourescence units.

${ }^{4}$ Percentage of surface myoglobin present in the oxymyoglobin state following $2 \mathrm{~h}$ at $4{ }^{\circ} \mathrm{C}$ exposed to atmospheric oxygen.

5 Percentage of surface myoglobin in the metmyoglobin state following incubation in $0.3 \% \mathrm{NaNO}^{2}$ at $20^{\circ} \mathrm{C}$ for $30 \mathrm{~min}$.

${ }^{6} \mathrm{n}=160$ for all variables except electron loss; $\mathrm{n}=91$ for electron loss.

$7 \mathrm{n}=40$ for all variables except electron loss; $\mathrm{n}=20$ for electron loss.

$8 \mathrm{n}=40$ for all variables except electron loss; $\mathrm{n}=19$ for electron loss.

$9 \mathrm{n}=40$ for all variables except electron loss; $\mathrm{n}=22$ for electron loss.

$10 \mathrm{n}=40$ for all variables except electron loss; $\mathrm{n}=24$ for electron loss. 
reducing activity, respectively) were much lower in longissimus lumborum steaks from the dark cutting classes than in the longissimus lumborum steaks from Control carcasses. As a result, the percentage of change in these traits was not comparable across dark cutting classes. Thus, the level of oxymyoglobin on the steak surface after allowing two hours for oxygenation (bloomed $\mathrm{OMb}$ ) was used as a measure oxygen consumption. Moreover, the initial amount of surface metmyoglobin (initial metmyoglobin) after incubation with sodium nitrite was used as a measurement of resistance to oxidation, which has been suggested an optimal measure of reducing ability (Mancini, Seyfert, \& Hunt, 2008).

As noted earlier, bloomed oxymyoglobin levels were much greater $(P<0.05)$ in longissimus lumborum from the Control class than all other dark cutting severity classes. As dark cutting severity increased, the concentration of bloomed oxymyoglobin decreased. This is likely a result of greater functionality in the respiration machinery at higher muscle pH. Bendall (1972) reported that mitochondrial oxidation is $50-75 \%$ higher at a $\mathrm{pH}$ of 7.2 than at a $\mathrm{pH}$ of 5.8 . As a result, greater respiration by mitochondria maintained a lower concentration of oxymyoglobin by competing with myoglobin for the available oxygen. In agreement, Lawrie (1958) concluded that increased concentration of deoxymyoglobin was due to increased oxygen consumption and decreased availability of oxygen to bind to myoglobin in meat.

Differences detected across dark cutting classes for nitric oxide metmyoglobin reducing activity were similar to those detected of bloomed oxymyoglobin. Decreased initial metmyoglobin formation in dark cutting carcasses compared to Control carcasses could be due to greater functionality of reducing mechanisms at higher muscle $\mathrm{pH}$. Giddings (1974) suggested that mitochondria or sub mitochondrial particles could potentially play a role in metmyoglobin reduction in vacuum packed meat cuts by scavenging residual oxygen, thus eliminating the potential for low-oxygen-mediated myoglobin oxidation. Additionally, the mitochondria could serve as a source of reducing equivalents for mitochondrial pyridine nucleotide reduction, which would provide the NADH necessary for metmyoglobin reductase to function properly (Bodwell, Pearson, \& Fennel, 1965; Giddings, 1977). Ashmore, Parker, and Doerr (1972) reported that mitochondria in normal muscle tissue rapidly lost capacity for respiration due to a decreased muscle $\mathrm{pH}$ and respiration was maintained at higher levels and for longer time periods in dark cutting beef.

\section{Conclusions}

Results from this study suggest that dark cutting carcasses favored oxidative metabolism. Carcasses classified as more Severe dark cutters had greater mitochondrial abundance than those classified as less Severe dark cutters or controls. Moreover, dark cutting carcasses generally had greater myoglobin concentrations than controls. Carcasses classified as dark cutters also exhibited decreased mitochondrial efficiency compared to controls selected from the same production lots. These conditions appeared to combine to cause glycogen depletion in the animals producing dark cutting carcasses.

The dark cutting condition has long been attributed to depletion of muscle glycogen in response to stressful stimuli prior to slaughter. However, the dark cutting condition occurs only sporadically and, generally, only a small number of animals in a given production lot will deplete glycogen and produce dark cutting carcasses, although all animals in the production lot were exposed to the same stimuli. Thus the depletion of glycogen is not solely due to the occurrence of the stimuli. The results of the present experiment suggest that greater dependence on oxidative metabolism, coupled with less efficient energy production by respiration may predispose animals to glycogen depletion, and consequently, the dark cutting condition, because a greater amount of glycogen would need to be utilized to provide the ATP needed to fuel the stress response.

\section{Conflict of interest}

There are no conflicts of interest. Mention of trade names, proprietary products, or specified equipment does not constitute a guarantee or warranty by the USDA and does not imply approval to the exclusion of other products that may be suitable. USDA is an equal opportunity provider and employer.

\section{Acknowledgments}

The authors are grateful to Patty Beska, Kristen Ostdiek, and Pat Tammen of the US Meat Animal Research Center for their assistance in the execution of this experiment and to Jody Gallagher of the US Meat Animal Research Center for her secretarial assistance.

\section{References}

AMSA (2012). Meat color measurement guidelines. Champaign, IL: American Meat Science Association.

Ashmore, C. R., Carrol, F., Doerr, L., Tompkins, G., Stokes, H., \& Parker, W. (1973) Experimental prevention of dark-cutting meat. Journal of Animal Science, 36, 33-36.

Ashmore, C. R., Doerr, L., Foster, G., \& Carrol, F. (1971). Respiration of mitochondria isolated from dark-cutting beef. Journal of Animal Science, 33, 574-577.

Ashmore, C. R., Parker, L., \& Doerr, L. (1972). Respiration of mitochondria isolated from dark cutting beef: Postmortem changes. Journal of Animal Science, 34, 46-48.

Bendall, J. R. (1972). Consumption of oxygen by muscles of beef animals and related species, and its effect on color of meat. I. Oxygen-consumption in pre-rigor muscle. Journal of the Science of Food and Agriculture, 23(1), 61-72.

Bodwell, C. F., Pearson, A. M., \& Fennel, R. A. (1965). Post-mortem changes in muscle. III. Histochemical observations in beef and pork. Journal of Food Science, 30, 944-954.

Bottje, W., Iqbal, M., Tang, Z., Cawthon, D., Okimoto, R., Wing, T., \& Cooper, M. (2002) Association of mitochondrial function with feed efficiency within a single genetic line of male broilers. Poultry Science, 81(4), 546-555.

Calkins, C. R., \& Hodgen, J. M. (2007). A fresh look at meat flavor. Meat Science, 77(1), 63-80.

Cawthon, D., McNew, R., Beers, K., \& Bottje, W. (1999). Evidence of mitochondrial dysfunction in broilers with pulmonary hypertension syndrome (Ascites): Effect of t-butyl hydroperoxide on hepatic mitochondrial function, glutathione, and related thiols. Poultry Science, 78(1), 114-124.

England, E. M., Matarneh, S. K., Scheffler, T. L., Wachet, C., \& Gerrard, D. E. (2014). pH inactivation of phosphofructokinase arrests postmortem glycolysis. Meat Science, 98(4), 850-857.

Giddings, G. G. (1974). Reduction of ferrimyoglobin in meat. CRC Critical Reviews in Food Technology, 5, 143-173.

Giddings, G. G. (1977). The basis of color in muscle foods. CRC Critical Reviews in Food Science and Nutrition, 9, 81-114.

Grubbs, J. K., Fritchen, A. N., Huff-Lonergan, E., Dekkers, J. C. M., Gabler, N. K., \& Lonergan, S. M. (2013). Divergent genetic selection for residual feed intake impacts mitochondria reactive oxygen species production in pigs. Journal of Animal Science, 91(5), 2133-2140.

Hanson, D. J., Kirchofer, K., \& Calkins, C. R. (2001). The role of muscle glycogen in dark cutting beef Available from <http://digitalcommons.unl.edu/animalscinbcr/298.> (Accessed February 10, 2013).

Hoffman, K., \& Hamm, R. (1978). Sulfhydryl and disulfide groups in meats. Advanced Food Research, 24, 1-111.

Hunt, M. C., \& Hedrick, H. B. (1977). Chemical, physical, and sensory characteristics of bovine muscle from four different quality groups. Journal of Food Science, 42(3), 716-720.

Iqbal, M., Pumford, N., Tang Z., Lassiter, K., Ojano-Dirain, C., Wing T., ... Bottje, W. (2005) Compromised liver mitochondrial function and complex activity in low feed efficient broilers are associated with higher oxidative stress and differential protein expression. Poultry Science, 84(6), 933-941.

Iqbal, M., Pumford, N. R., Tang, Z. X., Lassiter, K., Wing, T., Cooper, M., \& Bottje, W. (2004) Low feed efficient broilers within a single genetic line exhibit higher oxidative stress and protein expression in breast muscle with lower mitochondrial complex activity. Poultry Science, 83(3), 474-484.

Iwata, H., Goto, H., Tanaka, H., Sakaguchi, Y., Kimura, K., Kuwayama, T., \& Monji, Y. (2011) Effect of maternal age on mitochondrial DNA copy number, ATP content and IVF outcome of bovine oocytes. Reproduction Fertility Development, 23(3), 424-432.

Joo, S. T., Kauffman, R. G., Kim, B. C., \& Park, G. B. (1999). The relationship of sarcoplasmic and myofibrillar protein solubility to colour and water holding capacity in porcine longissimus muscle. Meat Science, 52, 291-297.

Keller, R. J., Halmes, N. C., Hinson, J. A., \& Pumford, N. R. (1993). Immunochemical detection of oxidized proteins. Chemical Research in Toxicology, 6, 430-433.

King, D. A., Shackelford, S. D., \& Wheeler, T. L. (2011). Relative contributions of animal and muscle effects to variation in beef lean color stability. Journal of Animal Science, 89, 1434-1451.

Kolath, W. H., Kerley, M. S., Golden, J. W., \& Keisler, D. H. (2006). The relationship between mitochondrial function and residual feed intake in Angus steers. Journal of Anima Science, 84(4), 861-865. 
Lawrie, R. A. (1958). Physiological stress in relation to dark cutting beef. Journal of Science and Food Agriculture, 9(11), 721-727.

Mancini, R. A., Seyfert, M., \& Hunt, M. C. (2008). Effects of data expression, sample location, and oxygen partial pressure on initial nitric oxide metmyoglobin formation and metmyoglobin-reducing-activity measurement in beef muscle. Meat Science, $79(2), 244-251$.

Marson, E. P., Ferraz, J. B. S., Meirelles, F. V., Baliero, J. C. C., \& Eler, J. P. (2008). Effects of polymorphisms of LHR and FSHR genes on sexual precocity in Bos taurus $\times$ Bos indicus beef composite beef population. Genetics and Molecular Research, 7(1), 243-251.

Martinaud, A., Mercier, Y., Marinova, P., Tassy, C., Gatellier, P., \& Renerre, M. (1997). Comparison of oxidative processes on myofibrillar proteins from beef during maturation and by different model oxidation systems. Journal of Agricultural and Food Chemistry, 45, 2481-2487.

Miller, K. D., Ellis, M., Sutton, D. S., McKeith, F. K., \& Wilson, E. R. (2000). Effects of live animal sampling procedures and sample storage on the glycolytic potential of porcine longissimus muscle samples. Journal of Muscle Foods, 11, 61-67.

Monin, G., \& Sellier, P. (1985). Pork of low technological quality with a normal rate of muscle $\mathrm{pH}$ in the immediate post-mortem period: The case of the Hampshire breed. Meat Science, 13, 49-63.

Moore, M. C., Gray, G. D., Hale, D. S., Kerth, C. R., Griffin, D. B., Savell, J. W., ... O'Connor, M. E. (2012). National Beef Quality Audit-2011: In-plant survey of targeted carcass characteristics related to quality, quantity, value, and marketing of fed steers and heifers. Journal of Animal Science, 90, 5143-5151.

NAMP (2003). The meat buyers guide. Reston, VA: North American Meat Processors Association.

Ojano-Dirain, C. P., Iqbal, M., Cawthon, D., Swonger, S., Wing, T., Cooper, M., \& Bottje, W (2004). Determination of mitochondrial function and site-specific defects in electron transport in duodenal mitochondria in broilers with low and high feed efficiency. Poultry Science, 83(8), 1394-1403.
Page, J. K., Wulf, D. M., \& Schwotzer, T. R. (2001). A survey of beef muscle color and pH. Journal of Animal Science, 79(3), 678-687.

Reznick, A. Z., \& Packer, L. (1994). Oxidative damage to proteins: Spectrophotometric method for carbonyl assay. Methods in Enzymology, 233, 357-363.

Rhoades, R. D., King, D. A., Jenschke, B. E., Behrends, J. M., Hively, T. S., \& Smith, S. B. (2005). Postmortem regulation of glycolysis by 6-phosphofructokinase in bovine M. Sternocephalicus pars mandibularis. Meat Science, 70(4), 621-626.

Shackelford, S. D. Wheeler, T. L. \& Koohmaraie, M. (2003). On-line prediction of yield grade, longissimus muscle area, preliminary yield grade, adjusted yield grade, and marbling score ising the MARC beef carcass image analysis system. Journal of Animal Science, 81, 150-155.

Souza, C. M., Boler, D. D., Clark, D. L., Kutzler, L. W., Holmer, S. F., Summerfield, J. W., ... Killefer, J. (2011). The effects of high pressure processing on pork quality, palatability, and further processed products. Meat Science, 87(4), 419-427.

Tarrant, P. V., \& Mothersill, C. (1977). Glycolysis and associated changes in beef carcasses. Journal of Science and Food Agriculture, 28, 739-749.

USDA (1996). Institutional Meat Purchase Specifications Fresh Beef Series 100 USDA Agricultural Marketing Service. Available from: USDA. (1996). Available from: https://www. ams.usda.gov/sites/default/files/media/IMPS_100_Fresh_Beef\%5B1\%5D.pdf Accessed February 11, 2016.

Wulf, D. M., Emnett, R. S., Leheska, J. M., \& Moeller, S. J. (2002). Relationships among glycolytic potential, dark cutting (dark, firm, and dry) beef, and cooked beef palatability. Journal of Animal Science, 80(7), 1895-1903.

Xiong, Y. L. (2000). Protein oxidation and implications for muscle food quality. In E. A. Decker, C. Faustman, \& C. J. Lopez-Bote (Eds.), Antioxidants in Muscle Foods. New York, NY: Wiley. 